\title{
Recruitment or enlistment? Individual integration into the Turkish Hezbollah
}

\author{
Mustafa Coşar Ünal ${ }^{\mathrm{a}}$ and Tuncay Ünal ${ }^{\mathrm{b}}$ \\ ${ }^{a}$ Department of Political Science and Public Administration, Bilkent University, Bilkent, Ankara, \\ Turkey; ${ }^{\mathrm{b}}$ Independent Researcher
}

\begin{abstract}
Radicalization and pathways to terrorism have been issues of dispute which owe their complexity to multiple dimensions and perspectives from different disciplines at different levels. This study focuses on the two competing perspectives on joining violent radical groups represented in the HofmanSageman debate: recruitment/facilitation or enlistment. It also elaborates on affiliative factors (kinship/first-circle-peers) and religiosity to analyze the conditions under which university students were drawn into Turkish Hezbollah (TH), a terrorist organization in Turkey. By using individual-level self-report data this study finds that kinship structures had a determinative impact on individuals' enlistment through 'Social Learning,' specifically, on embracing TH membership as a 'favorable definition' and/or a 'norm' within their original habitat. Yet, weakened 'Social Control/Bond' from home/original habitat made students significantly more vulnerable to TH's recruitment structures. This study argues that both approaches - recruitment and enlistment - have substantial explanatory power; however, under certain underlying sociological conditions. In that while weakened social bonds supplement recruitment, having militants in kinship structures particularly make young college students vulnerable to be drawn into violent radical networks through enlistment. This study also asserts that neither the religiosity of militants nor that of their families had a statistically significant effect on their integration into TH.
\end{abstract}

ARTICLE HISTORY Received 25 April 2017; Accepted 30 August 2017

KEYWORDS Radicalization; violent extremism; recruitment-enlistment; terrorism; Turkish Hezbollah

\section{Introduction}

Why individuals become terrorists has long been an important policy issue. However, individuals' radicalization and their engagement with terrorist groups have gained relevance with the latest wave of 'modern terrorism,' namely religious-oriented terrorism. Particular attention has been directed at behavioral radicalization that culminates in violent extremism, given the major threat that radical religious terrorism poses to countries across the

CONTACT Mustafa Coşar Ünal cosar.unal@bilkent.edu.tr $\Theta$ Department of Political Science and Public Administration, Bilkent University, 06800 Bilkent, Ankara, Turkey

(c) 2017 Informa UK Limited, trading as Taylor \& Francis Group 
world. Within this context, individuals' integration into and/or engagement with terrorist groups has become a growing concern for policymakers dealing with security.

Due to the fact that terrorism itself is a complex and multidisciplinary phenomenon, studies into why and how individuals engage in terrorist networks reach multidimensional and multifaceted conclusions. ${ }^{1}$ Within this context, this study aims to further the understanding of the existing conditions and certain affiliative factors driving young college students to integrate (partially through facilitation and recruitment efforts) into a religiously motivated terrorist organization. Radicalization of young college students has gained particular attention, especially the notorious example of Mohammed Emwazi known as 'Jihadi John' - who had been through the British higher education system. Emwazi's case brought up many questions on radicalization of young college students and the role of universities and related conditional dynamics that constitute a pathway to violent radical groups. ${ }^{2}$ Universities are considered significant meeting points or birthplaces of radicalization, ${ }^{3}$ and radicalization has become a growing problem in and around universities. ${ }^{4}$ Within this context, this particular study focuses on college students in Turkish higher education and identifies the conditional and contextual dynamics in their integration into/engagement with Turkish Hezbollah (TH hereafter), a religiously motivated terrorist organization that emerged in the early 1980s in Turkey. In so doing, it elaborates on the conditions and factors that render young college students vulnerable to being drawn or atrisk population to be dragged into a terrorist group - TH in this case - and the intervening role of institutional structures set up by TH itself.

Radicalization means different things in different contexts ${ }^{5}$ but, in the most generic sense, it has two types: cognitive and behavioral ${ }^{6}$ or non-violent and violent. ${ }^{7}$ While they are interrelated and might be part of an inclusive developmental process, individuals' use of extremist violence comes out as a result of behavioral radicalization. Within this process, there is an academic debate known as Hoffman-Sageman debate - over whether individuals are led to perpetrate terrorist violence by motives and social movements or by existing organizations' deliberate operational and strategic control over networks conducting terrorist attacks. ${ }^{8}$ By the same token, Borum ${ }^{9}$ argued that with regard to the role of facilitation - the recruiting effort/activities that draw individuals into violent radical groups ${ }^{10}$ - there are two competing perspectives: one which argues that the process of radicalization is mostly facilitated by systematic and intentional actors/recruiters; ${ }^{11}$ and the other ${ }^{12}$ which credits less to facilitation - asserting that no one is purely recruited into armed jihad - and more to enlistment, in that individuals want to join as part of their radicalization process. Also, a majority of people join jihadi groups through friendship and kinship structures through social learning. ${ }^{13}$ So, the conditions conducive to drawing young college students into violent radical 
groups are considered an important policy matter within the entire process of radicalization in general, and the pathway to extremist violence (behavioral radicalization) in particular.

In our research, we attempt to analyze certain conditions located at the aforementioned dichotomy of 'recruitment-enlistment' and to identify what sociological conditions related to the families of young college students in Turkish higher education lead them to integrate into TH. Does recruitment or enlistment play the most important role? How do certain conditional differences concerning the families influence their engagement with violent radical groups? What part does kinship/friendship (as Sageman argued) play in the conditions in which young college students are drawn into violent radical groups? Drawing on crime theories of how individuals deviate to engage in crime, we elaborate the on sociological conditions (e.g. lack of social control, kinship structures, facilitation structures designed and exploited by $\mathrm{TH}$, identity and values gained from families through social learning) conducive for young college students' integrating into $\mathrm{TH}$.

We should note that this study does not assert that the pathway to terrorism comprises a single set of conditions. Rather it accepts that radicalization is mostly a developmental issue in which there are many pathways that are affected by various factors; that each individual's radicalization process may be unique; that the radicalization is itself a dialectical process rather than a single decision; ${ }^{14}$ and that there are multiple types of terrorist activities and groups and each of these may change over time. However, out of such multiplicity, the condition that this research specifically focuses on is the preliminary (already set-in) condition that creates more vulnerability and helps draw young college students in Turkish higher education to $\mathrm{TH}$, a terrorist organization in Turkey.

Moreover, as Brown and Saeed ${ }^{15}$ asserted, the process of radicalization has remained undetermined and, in most cases, it is limited to attributions of signs of radicalization in vulnerable and/or at-risk populations. This is where this research seeks to identify the very condition that makes young college students more at-risk. As social movement theory (SMT) asserts, recruiters from movements conceive two consecutive stages in which they first act as rational prospectors to locate vulnerable and at-risk individuals as likely targets, and then deploy inducements to persuade them to engage with the organization. ${ }^{16}$ It thus regards social bonds and relationships - as Borum ${ }^{17}$ suggested - and active grooming - as McGlynn and $\mathrm{McDaid}^{18}$ argued - as critical in recruitment networks. This is the context wherein this study analyzes sociological conditions and their role in drawing young individuals into TH in the environment of the 1980s, 1990s, and early 2000s in Turkey (before the internet and social media began affecting Turkish society).

Within the aforementioned context, and different from most other studies, theoretical perspectives, and models (discussed below), in explaining 
integration into terrorist organizations this study draws from important components of two main criminological theories, namely Aker's social learning theory and Hirschi's social control theory. Social control theory argues that an individual who leaves his or her native habitat lacks the traditional social forces and bonds that could restrain his or her involvement in criminal activity. ${ }^{19}$ Social learning theory contends that an individual is more inclined to learn behavior through interaction with others who may serve as the stimuli for committing crime. ${ }^{20}$ While these two theories seemed to argue contradictory approaches in explaining individuals' engagement in crime, certain elements are found to be complementary or supplementary. ${ }^{21}$ By dwelling on certain specific and crucial elements such as the impact of institutional structures set up by the terrorist group (e.g. bookstores, mosque-oriented activities, provision of accommodation facilities for junior college students), the impact of social networks (i.e. whether or not individuals have members within their family and/or within their close circle of relatives and peers), existence of social control (i.e. whether or not the college student was away from his or her family to attend the college at the time of integration) and so forth (elaborated in the conceptual model), the influence of religiosity (whether or not individuals or their families were religious at the time of integration), this study identifies explanatory values in the recruitment-enlistment debate by elaborating certain underlying factors in one's integration into TH. By using individual-level self-report data, this study conducts quantitative analysis (logistics regression) in addition to certain descriptive level content analyses (of militants' self-reports) to address the students' integration into the $\mathrm{TH}$.

This study contributes to the fields of both terrorism and crime in different respects. First, it studies Turkish Hezbollah, which is an understudied organization that violently left its mark on Turkish political history in the 1980s and 1990s. Second, the literature has very limited data-based analysis on this group. Third, it uses original data from the terrorist group itself; the literature has very few empirical studies with similar data. Many scholars have argued that the bulk of research on radicalization is exploratory rather than explanatory and that empirical research is thin. ${ }^{22}$ Given that most of what has been written in radicalization studies is conceptual, this research attempts to empirically contribute to the field by questioning certain sociological conditions stemming from the role of families that are conducive to young college students' engagement with a terrorist group. Another important dispute within the literature is whether radicalization is a product of religious ideology/values or the outcome of social exclusion and/or alienation. This research seeks to empirically identify whether or not the religiosity of individuals and their families played a meaningful part in individuals' engagement with the violent radical group in a Muslim society, and quantitatively analyzes whether or not ideology/religiosity (of either the individual or his/her parents) 
served as a proxy or precursor to their integration into the terrorist group. Also, this study attempts to identify the underlying factors of conditions conducive to young college students' integration into a terrorist group, TH in this case, by drawing on criminological perspectives.

Toward these ends, this study first engages in a literature review regarding (i) radicalization and individual integration into terrorist organizations focusing on youth and family; (ii) crime theories of social control and social learning, and (iii) a brief discussion of TH by introducing its historical context, emergence, evolution, strategy, ideology, and goals, and prominent violent acts along with other relevant aspects. Second, it discusses the research method, design, conceptual and empirical models, data (i.e. collection of data, sample frame and population, operationalization of variables), and the analysis technique used for the analyses. Third, it presents the results and discusses them in light of the current literature and prior findings. Finally, it ends with concluding remarks.

\section{Literature review}

The factors and motivations that drive an individual to use violence in a violent radical organization are multidimensional and multilayered. ${ }^{23}$ There are push and pull factors operating at different levels/layers, i.e. individual, group (e.g. family and peers), communal, societal, national, and international that might influence one's decision to resort to terrorist activities. ${ }^{24}$ Second, these factors and motivations are multifaceted and multidimensional at each of these layers, ${ }^{25}$ being social, political, economic, and psychological. ${ }^{26}$ In this regard, each individual's integration into a terrorist organization may be a unique process of coupling/interaction and intersection of these multilayered and multidimensional factors ${ }^{27}$ indicating no consistent set of factors. ${ }^{28}$ Even the ideology is found not to be the determinative factor in one's decision to join and commit acts of violence, ${ }^{29}$ rather, it is mostly developed after one's participation and service in a terrorist group because a terrorist action itself is self-perpetuating. ${ }^{30}$

There is consensus that radicalization as a notion, apart from how one becomes a terrorist, is a complex and contested phenomenon. ${ }^{31}$ While there are two types of radicalization - cognitive and behavioral; ${ }^{32}$ or violent and non-violent ${ }^{33}$ - these two are interrelated and may both be part of an inclusive development process. In this regard, studies of radicalization have encompassed many different factors including psychological, behavioral, political, ideological, and religious, ${ }^{34}$ and thus have reflected different perspectives and approaches from different dimensions at different layers. While certain studies have focused on relative deprivation at both group ${ }^{35}$ and individual $^{36}$ levels, others have focused on situational factors that drive people into terrorist groups. Moreover, some studies have emphasized personal 
traits $^{37}$, while others have dwelled on situational factors that draw individuals into terrorism. ${ }^{38}$ Yet, certain studies have asserted that the experience of discrimination ${ }^{39}$ or lack of integration, exclusion, and alienation ${ }^{40}$ is a prominent radicalization factor that culminates in one's integrating into a terrorist group.

The focus of this research is the point where an individual integrates into a terrorist organization. Crenshaw ${ }^{41}$ asserts that an individual's motivation for joining a terrorist organization can be classified into theoretical models that include an individual's search for identity, need for belonging, perception of injustice, and ideology among others. Other scholars identify the first step of radicalization as becoming receptive to radical views and thus becoming vulnerable to joining terrorist groups. ${ }^{42}$ Despite such complexity for joining violent terrorist groups, there is relative consensus on the role of affiliative factors on individuals' engagement/integration in terrorist organizations. ${ }^{43}$ Research indicates that active grooming ${ }^{44}$ and affiliative factors ${ }^{45}$ play a significant role in one's decision to join - as well as exit from - a terrorist organization. These affiliative factors include personal relationships, social networks, and a sense of group/community belonging. Within this context, one's integration into a terrorist group is not comprised solely of individuals' motivation and perception of the world (ideology), but, among others, it is considered to be an interactive (dialectical) process of various dynamics such as interpersonal relations with other individuals and their external surroundings/influences, macro-scale events and socio-political developments in society, social bonds and societal control (beliefs of norms), and government policies. $^{46}$

The existing debate in the literature focuses on whether it is more about the recruitment or enlistment that lead young college students' engagement in terrorist groups. Some scholars underline the role of systematic and strategic facilitation as part of recruitment efforts, ${ }^{47}$ while others ${ }^{48}$ assert that armed jihad is more about individuals wishing to join - or enlistment. While these two may be interlinked, most scholars accept that active grooming through friendship and kinship (social learning) plays an important role. Families, therefore, are considered to play a significant role in individuals' radicalization and engagement with violent radical groups because they influence individuals' identity and thus the norms and values they embrace. ${ }^{49}$ In this respect, families are associated with psychological and socialization risk factors in one's cognitive opening to both violent and non-violent radicalization. While psychological factors involve identity and trauma, socialization relates to one's exposure to radical views through kinship/friendship/peer (social) structures that lead one to embrace those values as original norms. ${ }^{50}$ Leaving aside psychological trauma, which is out of this study's scope, the identity and values gained from families as part of one's personality development are critical to the process of radicalization into violent extremism. ${ }^{51}$ In addition to the psychological perspective, socialization in 
kinship and peer structures plays an important role in one's 'identity-related' and/or 'ideologically driven' activism, which in this case is first cognitive then behavioral radicalization into violent extremism. As Bigo et al. and Van San, Siekelinck, and Winter. ${ }^{52}$ assert, beyond norms and values, individuals with activists in their close family circle are provided with networks and capabilities of that particular activist group/organization. In addition to this, being disconnected from family may increase the risk factors for a young individual's receptivity to radical views. ${ }^{53}$ In other words, the weakening of individuals' bonds to their original habitat and social bonds to family renders them more cognitively open and receptive to new bonds within new environments, and thus creates vulnerabilities for deviation. ${ }^{54}$

Within this context, terrorist networks' deliberate actions play an important role in which they exploit all the 'push and pull' factors to constitute a fertile/breeding ground that prepares at-risk individuals for easy recruitment. As suggested by proponents of the SMT, recruiters act as rational prospectors in locating vulnerable and at-risk individuals as likely targets and then they use inducements to persuade them into joining the organization. In so doing, terrorist organizations design certain institutional structures (e.g. particular bookstores, publications, ideology-oriented social community organizations, and social media tools) or circulate networking activities around social/communal settings parallel to their ideology likes mosques (as religious settings) or schools and universities (as educational settings) to gain new recruits as well as to spread their ideology for more popular support. ${ }^{55}$

On the other hand, when and if families are supportive (as part of rehabilitation processes used in many de-radicalization programs), they may help prevent radicalization into extremist violence ${ }^{56}$ or help in de-radicalization. ${ }^{57}$

Overall, individual engagement/integration into terrorist organizations is a dynamic and multi-step process in which an individual embraces extremist views that are tied to violence to realize certain goals, and thus, comes to psychologically/cognitively legitimize the use of terrorist violence as an acceptable course of action. ${ }^{58}$ Also, individuals' deviant behavior during their involvement in terrorist activities involves internal (self-directed) and external (social) interactions in which factors related to control and learning play significant roles. However, there are certain favoring conditions that lead and/or are used to draw individuals into terrorist networks, which is the focus of this research.

Given that no single set of factors (the aforementioned multilayered and multidimensional factors that make conditions conducive to terrorism for individuals and groups) can precisely and sustainably explain one's integration into radicalized terrorist organizations, and the only consensus on the issue is affiliative factors, this study focuses on the existing socialization conditions at the recruitment-enlistment dichotomy that lead to individuals' engagement with violent radical groups. In doing so, it leans on the basic 
elements of two main criminological theories: social learning theory and social control theory.

While the similarities and differences of crime and terrorism are beyond the scope of this study, it would be helpful to briefly discuss terrorism and crime. Terrorism is considered to be a crime (legally speaking) but certain characteristics of terrorism that reflect particular differences have been a matter of debate. Conventional approaches have claimed that the major difference between terrorism and crime is reflected by theory and policymaking. For instance, scholarly literature that considers terrorism as a form of crime is controversial due to the terrorism's distinct motives. ${ }^{59}$ While criminals do not seek to achieve policy change, terrorists embrace goals that demand policy change in social, economic, and/or political context. Contrary to criminals who may be motivated to perpetrate crime for its own sake, terrorists resort to use of violence as a means to reach specific political ends. ${ }^{60}$ In addition, most terrorist organizations engage in criminal activities (in addition to terror as a crime) to financially support their campaign and sometimes these activities outweigh their terrorist activities. For instance, although the revolutionary armed forces of Colombia (FARC) were formerly a politically motivated terrorist organization, they currently profit from drug trafficking, and its members act criminally to gain financial freedom. This also holds for many cases around the world in which political rebels have been involved in additional activities to financially support their violent political campaigns. To illustrate, Lebanese Hezbollah, Al-Qaeda, PKK, and Hamas operate sophisticated fundraising networks across the world. ${ }^{61}$

Moreover, Ferracuti ${ }^{62}$ claims that terrorist actions begin with legal and accepted forms of dissent such as individual oral protests or petitions that can easily evolve into illegal but often tolerated acts, for example, violent demonstrations, vandalism, or seizures of property. Eventually, these actions escalate to unacceptable and illegal behavior, including sabotage, personal assaults, bombings, and kidnappings. Considering these actions, according to Ferracuti, terrorists should be approached as criminals. As terrorism often involves various kinds of crime, including kidnapping, arson, murder, and conspiracy, it is very difficult to make a distinction between terrorism and crime. ${ }^{63}$ Besides being involved in the same illegal activities, other similarities between terrorists and criminals include the actions and tactics employed by both groups. ${ }^{64}$ More importantly, as previously mentioned, ideology is not found to have a primary effect on individual's decision to join a terrorist group, ${ }^{65}$ which indicates that a criminological approach is relevant.

Although there are differences of opinion about how terrorism and criminality are related, this study applies the theories of social learning and social control to understand why individuals join terrorist groups because each theory explains why certain individuals may be prone to engage in crime as 
a deviant act. Within this context, this study uses the lenses of these two theories to focus on how members of the $\mathrm{TH}$ were first integrated into the organization.

\section{Social learning and social control}

Aker's social learning theory and Hirschi's social control theory have been examined on their validity in prediction of crime (and drug use of adolescents). Social control theory assumes that an individual who leaves his or her original habitat lacks the traditional social forces and bonds that could restrain his or her involvement in criminal activity. ${ }^{66}$ Social learning theory implies that an individual is more inclined to learn behavior through interaction with others who may serve as the stimuli for committing crimes. ${ }^{67}$

While many studies have tested these theories individually ${ }^{68}$ and comparatively, ${ }^{69}$ very few studies focused on individuals' engagement in terrorism as a crime ${ }^{70}$ which will be the focus of this study.

Briefly, the theory of social control developed by Hirschi ${ }^{71}$ argues that individuals are naturally deviant unless they are controlled. If the controlling force is missing then humans are prone to get involved in criminal activities and drug use. The basic notion of Hirschi's social control is based on the existence of the social bond between individuals and society. It assumes that so long as people are bound to society, deviance (involvement in crime) is kept in check because, naturally, people do not want to harm and or lose that bond. When an individual's bond to society is broken or weakened, the likelihood for that person to turn to crime becomes higher.

Hirschi's social bond includes four elements, namely, attachment, commitment, involvement, and belief. The value that individuals emotionally attribute to their relationships with significant others - particularly to their families and peers - constitutes the crucial element of the attachment. The element of attachment assumes there is a direct link between the strength of the attachment and the likelihood of crime involvement; individuals are less likely to engage in crimes when their bond with their social environmental circles such as parents/family members, peers is strong. Commitment - a rational element of social bond - is the devotion of time and energy to certain activities or institutions. When people make such investments they are less likely to engage in any activity (crime) that would risk damaging and/or losing them. Involvement similarly denotes the amount time spent by individuals in conventional activities. The more time spent, the less time people have to engage in criminal activities. Lastly, the belief of a person in social norms makes him/her less likely to act against those societal norms and thus less likely to get involved in crime.

Contrary to what Hirschi argued with social control, that humans are naturally deviant unless control is reinforced with social bonds, Akers's social 
learning theory argues that humans are neither inherently deviant nor inherently social; they are neutral. In this regard, Akers claims that what constitutes human behavior is the sum of his/her interactions with other individuals, groups, and social institutions rather than whether or not there are controls via social bond to restrain humans from deviating (in crime and drugs). Social learning theory is comprised of four different elements: differential association, definitions, differential reinforcement, and imitation. ${ }^{72}$ Definition refers to attitudes and/or meanings that a person attaches to a particular behavior during a process of human interactions with others (people, groups, and institutions). In this regard, when an individual has a greater number of definitions that are favorable to a deviant act/behavior then he/ she is more likely to engage in crime. Differential association is the process where an individual is exposed to these definitions (favorable or unfavorable) in his/her social interactions. Differential reinforcement denotes an individual's perceived balance of expected rewards (benefit) and punishment (cost) in his/her act and behavior. The balance of rewards and punishments influences individuals' definitions: when they are rewarded for a deviant act/ behavior than they are more likely to develop favorable definitions to that particular act/behavior and continue to engage in that deviant behavior. Imitation simply indicates that an individual is more likely to engage in certain (criminal in this case) behavior/acts as they observe similar behavior in others. $^{73}$

There are several studies that analyze the comparative ability of these theories to explain individuals' involvement in crime. Some studies ${ }^{74}$ found that elements of social control are better at predicting value in explaining delinquency (crime involvement). Others ${ }^{75}$ indicated more support for social learning in the prediction of crime involvement. However, certain studies found both theories explained the effect of broken homes on delinquency; Matsueda and Heimer ${ }^{76}$ found support for both theories, casting social control as a remote cause and social learning as a direct cause of delinquency. While results are mixed, social learning is found to have slightly more support than social control. ${ }^{77}$ There are also models that include elements from both theories to better explain adolescence delinquency. ${ }^{78}$ Certain studies, such as Conger ${ }^{79}$ argue that social control theory's notion of a combination of the social 'bonding' along with the components of social learning constitute the cornerstone for a more comprehensive theory of delinquent behavior than each perspective on its own.

\section{Turkish Hezbollah}

$\mathrm{TH}$ is a terrorist organization seeking to overthrow the secular Turkish Republic and replace it with a theocratic system ruled by Sharia. ${ }^{80} \mathrm{TH}$ emerged in Turkey's Batman province in 1980, following the Iranian 
Revolution, which was a major motivation and inspiration for the organization's emergence and ideological formation, but before the military coup of 12 September $19800^{81}$ Before officially declaring themselves Hezbollah (Hizbullah), they were known as Cemaata ${ }^{82}$ Ulemayên İslâmî (the Community of Islamic Scholars). ${ }^{83} \mathrm{TH}$ emerged from southeastern and eastern Turkey and based its most of its main activities in these regions. The provinces of Batman, Diyarbakir, Van, and Mardin have witnessed intense TH activity. No one single phenomenon can account for the emergence of the group. In addition to the socio-political context of Turkey in the 1980s, two factors were particularly significant: the Iranian Revolution and its reflections on Turkish society and the reaction to and grievances about the emergence of the Kurdistan Workers' Party (Partiye Karkeren Kurdistane abbr. PKK) from Turkey's discontented Kurdish population.

First, Iran's revolution made a big impact on certain religious and radical segments in Turkey and opened new horizons for them. Hundreds of young Islamists visited Iran, looking to transform Turkey into Iran. ${ }^{84} \mathrm{TH}$ was foremost of these. TH aimed to use the same means to achieve a similar goal in Turkey. Iran also provided support to TH: high-level TH leadership, including the founding leader Hüseyin Velioğlu received military, political, and religious training in Iran. One important piece of documentary evidence was an Iranian intelligence and national security agent ID card with the name of Huseyin Velioglu that was found during a police operation. ${ }^{85}$ Karmon further argues that other members of TH also got training in Iran. ${ }^{86}$ It should be noted, however, that despite the Iranian Revolution being a concrete blueprint for TH's ultimate goal, group members do not want to be controlled by Iran.

As for the second factor, the PKK's socio-political domination in the region provoked a religious reaction. This is because the PKK was founded as a socialist organization that had embraced Marxist-Leninist doctrine until the second half of the 1990s ${ }^{87}$ However, not all of Turkey's Kurds - who were socially heterogeneous, including both religious-traditionalists and socialists - supported the PKK's revolutionary struggle. ${ }^{88}$ In addition to the socialist segment, Kurdish activism was also evident among the religious/traditionalist Kurds. In fact, given the highly feudal structure of Turkey's southeastern and eastern provinces, the allegiances of most Kurdish activism was determined on a tribal basis in addition to their ideology. Some of the more religious/traditionalist Kurds have opted to join the provisional Village Guard System (Geçici Köy Koruculuğu Sistemi, GKK), ${ }^{89}$ while some others have supported the Turkish Hezbollah, or have remained neutral. Most Kurds killed by the PKK in the early years of the conflict were either from the GKKs or members of TH. ${ }^{90}$ Therefore, the PKK's killing of non-compliant Kurds ${ }^{91}$ and its anti-religious ideology in this initial period contributed to the TH's emergence and reaction to the PKK. The clashes between these two rival groups reached their peak in 1992, and around 500 members of the two 
groups were killed just from 1992 to 1995. Interestingly, the founding leaders of both the PKK and the TH, Abdullah Öcalan and Hüseyin Velioğlu, respectively, attended University of Ankara in the late 1970s. ${ }^{92}$

In order to better grasp the emergence and development of $\mathrm{TH}$, it is crucial to understand the socio-political context of Turkey in the 1980s. The contextual dynamics of the 1960s and 1970s featured big social and economic shifts in Turkey. These include industrialization and, in turn, high inflow of migration from rural areas to cities and resultant high urban unemployment. ${ }^{93}$ Turkey had also experienced intense political violence and leftist student movements, nationalist groups and religiously inspired groups took part in the social and political uprisings during this time. ${ }^{94}$ Tensions between these ideological poles escalated and resulted in extreme political violence. Attacks were carried out against symbolic targets of all dominating ideologies, namely communism, capitalism, and nationalism. ${ }^{95}$ Between 1975 and 1980, for instance, roughly 5000 people were killed as a result of political clashes between these groups and assassinations, bank robberies, kidnappings, and bombings had become commonplace. ${ }^{96}$ Through a study of National Security Council Bulletins, Rodoplu, Arnold, and Ersoy, ${ }^{97}$ reports that between 1978 and 1982, 43,000 fatal acts of political violence had been committed, averaging 28 deaths per day. Eligur $^{98}$ reports that politically motivated killings had reached more than 20 per day during the summer of 1980 . Such instability in social, political, and economic contexts, and particularly the violent escalations, induced the military coup of 1980. While the military justified its intervention as a restoration of public order by interrupting the period of intense violence between radical groups of left and right, it lost its legitimacy due to overreactions and wrongdoings that resulted in 650,000 arrests, 1,683,000 prosecutions, 517 death sentences, of which 49 were carried out and so forth. ${ }^{99}$ So, Turkey had been through high political tensions, violent clashes between opposite ideological groups and draconian security measures.

More importantly, what facilitated the mobilization of political Islam, including TH, was the new state ideology known as Turkish-Islamic Synthesis (TIS), which was initiated by the Turkish Military Council subsequent to the coup d'état of 1980. In order to mend ideological cleavages in the socio-political context and to prevent the recurrence of anarchy and violent clashes of the 1970s, the Turkish Military Council adopted a new concept called the 'Turkish-Islamic (a.k.a. Turco-Islamic) Synthesis,' which originated in the right-wing nationalist Intellectual Hearths (Aydınlar Ocakları) in the 1970s. The Military Council and ensuing governments promoted Sunni Islam as a unifying instrument to particularly surpass leftist movements. The TIS even supplanted the secular Kemalist ideology of the state. As a de-facto state ideology, TIS has made dramatic and long-lasting impacts on Turkey's socio-economic and socio-political contexts. ${ }^{100}$ Among others, the most crucial impact has been opening the door for organizational and framing activities by 
Islamist forces ${ }^{101}$ and their political mobilization. ${ }^{102}$ For example, not only was the number of vocational schools for training religious services personnel (Imam Hatip Liseleri) increased, but also Quranic courses became more widespread than ever before. ${ }^{103}$ Mosque-building activities increased steadily both by the state and by conservative groups and individuals. ${ }^{104}$ Religious movements (e.g. brotherhoods and Tarikats) arose and became more influential. The Religious Affairs Directorate had huge budget increases that resulted in new mosques and Quran courses as well as mandatory religion classes in state schools. ${ }^{105}$ In the end, the TIS created social and political space for Islamist mobilization, and thus development opportunities and venues for radical groups, including $\mathrm{TH}$.

A turning point in the Turkish authorities' attitude toward the radical religious groups occurred in March 1996. ${ }^{106}$ Until that point, Turkish authorities had underestimated these terrorist groups and did not hinder their activities. In March 1996, the arrest of Irfan Cagirici, the leader of the 'Islamic Movement,' another violent radical group in Turkey, made a dramatic change in Turkish security approach toward these groups. ${ }^{107}$ Irfan Cagrici and certain other militants' arrests and interrogations unveiled the story behind the killings of certain important Turkish secular intellectuals as well as the relationship between the Islamic Movement and Iran, which were directly involved in acts of terror against the Turkish Republic. ${ }^{108}$ From this date on, Turkey intensified its security operations against these groups. ${ }^{109}$

TH has used a three-stage progressive strategy: first, the message dissemination (irşad), then congregation (Jemaah), and finally, armed struggle (jihad). The message dissemination stage includes reaching out to the masses to promote their organizational ideology and popularize their goals. In this stage, $\mathrm{TH}$ published numerous books and magazines in an effort to gain more supporters. Bookstores and publishing centers set up by $\mathrm{TH}$ in this stage played a central role in that they were able to craft propaganda, to spread their ideologies to more people, and inform, organize, and even give orders to their members and supporters. The second stage involves establishing communities that had embraced TH's organizational ideology and goals. The third and the final stage is the jihad in which the organization commences its war through violent means. ${ }^{110}$

In the early 1990s, a significant dispute emerged over means and ends that culminated in the group splitting into two major parts: Ilim and Menzil. ${ }^{111}$ While the former was centered around 'Bookstore İlim' (İlim Kitabevi)) and commenced jihad as the third stage of their strategy, the latter found conditions premature for initiating jihad. This dispute became violent, and from 1993 to 1994 intergroup clashes resulted in nearly 100 deaths. ${ }^{112}$ The İlim group suppressed Menzil group and started their terror attacks. TH was also able to spread its activism and become an important actor in western provinces, particularly Istanbul. However, there are differing accounts. Kurt, ${ }^{113}$ 
for instance, argues that these two groups were already different and there was no split; he further claims that the Menzil group was a separate group operating in Diyarbakır rather than a Hezbollah offshoot in Batman. Moreover, there was another group called Vahdet, which was a small group of former Hezbollah members organized around the Vahdet Bookstore. ${ }^{114}$ Conflict between the group Vahdet and Ilim did not go beyond fights between high school students in comparison to the armed a conflict and killings between İlim and Menzil. ${ }^{115}$

What really revealed the extent of TH's clandestine activities were the security force operations conducted in Istanbul against the top council of TH. ${ }^{116}$ On January 17, 2000, Hüseyin Velioğlu, the leader of Hizbullah İlim faction, was killed and 61 high-level members were captured. The seizing of a database during this operation led a series of operations over the next two years through which Turkish National Police arrested a total of $4679 \mathrm{TH}$ members, ${ }^{117}$ and located and identified the bodies of 67 people who had been kidnapped and murdered by TH. It was only through these operations that the organization's responsibility for numerous killings and kidnappings came to light. ${ }^{118}$ Similarly, the brutal methods used by TH were revealed through confiscated videotapes showing members torturing and burying their victims alive. ${ }^{119}$

Turkish Hezbollah's worldview resembles that of a typical, radical, religionabusing terrorist organizations. Like many others today, e.g. Islamic State in Iraq and Syria (ISIS), they dehumanize and ostracize all those who do not embrace their ideology; ${ }^{120}$ it is 'us' versus 'them.' This is how they legitimized killing people whom they described as evil, including many secular intellectuals such as journalists, academicians, and activists. ${ }^{121}$

Turkish Hezbollah was very active as a terrorist organization between the mid-1980s and the early 2000s. They committed arson, kidnappings, and murders, and used Molotov cocktails, guns, and bombs. One of their most remarkable terrorist attacks was the 2001 assassination of the Police Chief of Diyarbakır Province along with five of his guards. ${ }^{122} \mathrm{TH}$ was also found responsible for several killings and disappearances of government staff, businessmen, journalists, security forces, and pro-PKK individuals. According to the official government records, between 1994 and 2006 TH carried out 523 terrorist incidents, killing 243 civilians and 22 civil servants and injuring 287 civilians and 49 civil servants. In the same period, the total figure for captured TH militants reached nearly $10,000 .{ }^{123} \mathrm{TH}$ did not attack the state and its representatives in its early phase of development and mostly targeted whomever they declared to be enemies, including pro-PKK figures. TH's battle against PKK members has led some to claim that the Turkish Government allowed or tolerated TH to operate. ${ }^{124}$

Since then, TH has remained active, particularly in prisons and abroad and has been reestablishing its leadership and to regain its support base. In 
recognition of their mistake in the early 1990s, the organization has avoided armed struggle due to the conditions for their jihad being premature. Unlike before, the organization has been seeking peace with other religious groups and organizations. Most importantly, TH advocates have mostly engaged in legal political activities through the Free Cause Party (Hür Dava Partisi, abbr. HUDA-PAR), founded in 2013 as a continuation of Mustazaf-der, and they continue proclamation efforts by publishing pro-TH books and periodicals in order to regain support from their communities (congregation). They have considerable popular support in Turkey's south and southeast region. In the 2014 local elections, in which they participated with independent candidates, they case certain important votes at the ballot. For instance, in Diyarbakur, the only metropolitan area in Turkey's southeast, HUDA-PAR received a 4.77\% of the overall votes. In their home province and main support base, Batman, they won $7.8 \%$ of the total votes. This figure was $5.58 \%$ in the province of Bitlis, 3.06\% in Bingöl, 2\% in Mardin, and 2.32\% in Şırnak. ${ }^{125}$

\section{Method}

This section introduces the conceptual model, discusses the nature and characteristics of the data, and provides a list of the variables used along with their operational definitions. It later introduces the empirical model to address the quantitative part of this research.

\section{Conceptual model}

The focus of this study is to analyze the sociological conditions that influence the relative importance of recruitment - institutional efforts that do not use kinship ties - and enlistment - a proclivity cultivated at the original habitat - by applying crime theories. In so doing, it examines underlying sociological conditions related to the role of families. It also questions the role, if any, of ideology/religiosity in individuals' engagement with TH. More specifically, by employing theories of social control and social learning it questions militants' social bond/attachment to their original habitat and their exposure to radical views through kinship to analyze how these certain parental (sociological) factors impact the recruitment-enlistment dichotomy.

This study adds to the understanding of the sociological conditions and role of families in individuals' integration into violent radical groups by analyzing the impact that a lack of social control/attachment (being away from family, relatives, and original habitat) and the kinship effect (social learning through TH militants within family, relatives, and first circle peers ${ }^{126}$ to constitute a norm) has on young college students' integration into $\mathrm{TH}$ in the context of the organization's strategic recruitment/facilitation effort and individuals' enlistment. 
In their self-reports, subjects provided data on how they were first introduced to $\mathrm{TH}$, their process of integration, and whether their families or the militants themselves were religious (practicing daily religious prayers as a critical threshold for being religious in Islamic theology) at the time of integration. These responses contain basic information that could be related to the main themes of social control and social learning theories:

- Whether having weak bonds due to being away from home, family, and original habitat (lacking certain elements of social control - bond and attachment) for their college education was a determinative factor in their integration (rendering them vulnerable) into $\mathrm{TH}$.

- Whether having TH militants in their families or close circles of relatives (the elements of social learning; differential association, attributing favorable definitions and imitation) and peer groups within original habitat were determinative for their membership in $\mathrm{TH}$.

- How, influential, if at all, militants' and/or their families' religiosity was on their integration into $\mathrm{TH}$ relating to the same dichotomy.

\section{Variables}

Dependent variable (DV): The DV is a binary approach that focuses on whether or not college students integrated into TH through TH's recruitment efforts around the institutions (e.g. activities around mosques and bookstores) set up by the organization for recruitment of new militants $(\mathrm{Yes}=$ ' 1 ,' $\mathrm{No}=$ ' 0 ').

$\mathrm{DV}=1$ : When a militant integrated into the TH through institutional structures, regardless of whether or not the TH member lived at home during college.

$\mathrm{DV}=0$ : If factors other than $\mathrm{TH}$ recruitment institutions had led the militant to integrate into TH during his/her college education, regardless of whether the militant had TH members in his/her social network (kinship) or whether he/she was away from family when attending college. Thus, other factors include being affected or motivated by social structures and certain other specific issues at the micro and macro levels. ${ }^{127}$ To illustrate, as a response to the question of why and how a subject integrated into the $\mathrm{TH}$, he/she stated that:

What got me into TH was its role against the PKK in the region. The PKK's campaign and fight against the Jemaah [referring to the $\mathrm{TH}$ ] resulted in many martyred Muslims, and I wanted to stand against it. I was also attracted to Iran's Islamic Revolution that I used to listen about on radio news. As a result, I personally decided to join the Jemaah (the TH) ...

The subject's answer indicates that the Iranian Revolution was a meso and macro-level motivator and his/her individual response/reaction to killed Muslim Kurds was a micro-level motivator. 
Independent variables (IVs): The IVs are whether or not college students have TH militants within their existing social network (kinship: family, relatives, and first circle peers) and whether or not these college students are away from their hometown (original habitat) for college education. In addition to these main IVs, two more IVs indicating the religiosity of the family and the college student him/herself are incorporated into the model. Since TH is a radical religious terrorist organization it is important to identify whether religiosity - of individuals themselves or the original social structures they were raised in - had a determinative factor in their integration into the organization.

IV $V_{1}$ : WITHORAWAYFAMILY: Attending college education away from their family (away $=1$, with $=0$ )

As discussed in the literature review, families are considered to have important roles on one's radicalization and de-radicalization. ${ }^{128}$ As Wali ${ }^{129}$ asserted, family disconnection may increase the risk factors for a young individual's radicalization: they may feel alienated from their original habitat and thus they may be more open and receptive to a cognitive bond shift. In one's deviance to a crime, as Gibbs ${ }^{130}$ argued, social control is one of the determinant factors. According to him, strong social control is a general deterrent to criminality. Given that terrorist groups often seek easy targets, colleges are attractive environments. ${ }^{131}$ Likewise, TH exploits freshmen students' need for new social bonds while away from home.

$I_{2}$ : MILINSOCNETWORK: having Hezbollah militants within the social network (have $=1$, have not $=0$ )

Because terrorists organize themselves as clandestine networks in order to cover their unlawful activities, they use relatively stable and reliable sources to recruit new militants. Sageman and Spalek ${ }^{132}$ inferred that family relations and peer groups are two important components that may lead an individual to join terrorist organizations. In Sageman's study of 172 militants, their biographical data revealed that other militants within their social networks made young Muslims more vulnerable for recruitment by terrorist organizations.

$I V_{3}$ : FAMILIYRELIGIOSITY: Whether or not the family is religious $($ religious $=1$, not $=0)$

IV $V_{4}$ MILITANTRELIGIOSITY: Whether or not the individual is religious (religious $=1$, not $=0$ )

Despite the fact that ideology is not found to have any primary effect in individuals' engagement with terrorist groups. ${ }^{133}$ Silberman ${ }^{134}$ argues that religion has effects on individuals on both ways either provoking or hindering terrorism depending on their interpretation. In this regard, the $\mathrm{IV}_{3}$ and $\mathrm{IV}_{4}$ identify whether or not the religiosity (of individuals and families) had an impact in college students' integration into TH. 


\section{Data}

This study uses individual-level self-reports (submitted to TH by its own militants) confiscated from TH's own database. ${ }^{135}$ The dataset contains information on TH members' lives both before and after integration. In addition to typical demographic questions (age, occupation, number of siblings, family situation, and so forth), self-reports contain information about the sociological conditions that led to members' integration into the organization. Given the scope and aim of this study, the entire population of young TH militants who integrated into $\mathrm{TH}$ during their college education is purposively selected and included in the analyses. The entire sample consists of $n=344 \mathrm{TH}$ members that fall under this category (educational levels of TH members are extremely low as part of the socio-cultural characteristics of Turkey's southeast region, where TH has been based). Self-reports have weaknesses and strengths compared to police and court records. However, the information from the reports used for this research is not considered to have critical reliability problems. This is because $\mathrm{TH}$ members would be unlikely to falsify information about themselves and their families as TH would probably verify these reports to further network. A deliberately falsified report would lead to an individual being considered an intruder and/or infiltrator. Members would not take such a risk considering the brutality that TH used against its opponents.

All of the variables are coded based on these self-reports that provided specific information regarding the aforementioned IVs. ${ }^{136}$ The DV, IV ${ }_{1}$, and $\mathrm{IV}_{2}$ are coded based on militants' answers to questions about their pre$\mathrm{TH}$ life, how and why they integrated into the $\mathrm{TH}$, and what and/or who was determinative for militant's integration and so forth. The $\mathrm{IV}_{3}$ and $\mathrm{IV}_{4}$ are coded based on what they about their lifestyle and religiosity (including that of their families) before joining the organization.

This study uses logistic regression to weigh the likelihood of each IV and focuses on addressing the role of social control and kinship in TH's strategic recruitment efforts to identify certain sociological conditions conducive for college students' integration into $\mathrm{TH}^{137}$

\section{Results}

This section presents the data analyses and findings. It does so by first plotting the frequencies and results from cross tabulations. Next, it runs a logistic regression to address the research question, and presents the results.

\section{Descriptive statistics}

With respect to the DV (recruitment through institutional structures versus other means), we find that among the 344 student-militants, $67.4 \%$ (232) were recruited through institutional structures (IS) set up by $\mathrm{TH}$ while the 
Table 1. Cross-tabulation for the DV (institutional structure or other) versus being with or away from family.

\begin{tabular}{|c|c|c|c|c|c|}
\hline \multicolumn{6}{|c|}{ Institutional structure $(\mathrm{IS})=1$, Other $=0 *$ with or away from family cross-tabulation } \\
\hline & & & With family & Away family & \\
\hline \multirow[t]{8}{*}{ IS $=1$ Other $=0$} & Other & Count & 91 & 21 & 112 \\
\hline & & $\%$ within IS = 1 Other $=0$ & $81.2 \%$ & $18.8 \%$ & $100.0 \%$ \\
\hline & & $\%$ within with or away from family & $46.0 \%$ & $14.4 \%$ & $32.6 \%$ \\
\hline & & $\%$ of total & $26.5 \%$ & $6.1 \%$ & $32.6 \%$ \\
\hline & IS & Count & 107 & 125 & 232 \\
\hline & & $\%$ within IS $=1$ Other $=0$ & $46.1 \%$ & $53.9 \%$ & $100.0 \%$ \\
\hline & & $\%$ within with or away from family & $54.0 \%$ & $85.6 \%$ & $67.4 \%$ \\
\hline & & $\%$ of total & $31.1 \%$ & $36.3 \%$ & $67.4 \%$ \\
\hline \multirow[t]{4}{*}{ Total } & & Count & 198 & 146 & 344 \\
\hline & & $\%$ within IS $=1$ Other $=0$ & $57.6 \%$ & $42.4 \%$ & $100.0 \%$ \\
\hline & & $\%$ within with or away from family & $100.0 \%$ & $100.0 \%$ & $100.0 \%$ \\
\hline & & $\%$ of total & $57.6 \%$ & $42.4 \%$ & $100.0 \%$ \\
\hline
\end{tabular}

integration of $32.6 \%$ (112) was related to other factors. As for whether or not these respondents studied away from their family (WITHORAWAYFAMILY), $42.4 \%$ (146) of them studied away from their family, while $57.6 \%$ (198) were with their family.

Cross-tabulation results are plotted in Table 1 to analyze and the relationship between the DV and the $\mathrm{IV}_{1}$ WithOrAwayFromFam. Results indicated that $85.6 \%$ of (125 out of 146$)$ TH militants who were away from their family during their college education integrated into the TH through institutional structures. On the other hand, as denoted in Table 1, this figure is 54\% (107 out of 198) for those who integrated though institutional structures while living with their families during college. This result indicates that the TH uses its institutional structure very effectively. ${ }^{138}$

Of the $344 \mathrm{TH}$ militants that integrated while attending college $28.8 \%$ (99) of them had Hezbollah militants within their family, relatives, and first circle peers while $71.2 \%$ (245) of them did not have any.

Cross-tabulation results for the DV and the $\mathrm{IV}_{2}$ MilinSocNetwork, as presented in Table 2, indicate that $90.9 \%$ (90) of TH militants who had militants within their families, relatives and peers (in their original habitat) integrated through their first circle social structures (peers, relatives, and family members) as opposed to institutional structures. It indicates the significance of kinship effect and it may be concluded that having Hezbollah militants within social structure has a significant and almost determinative effect on college students' integration into $\mathrm{TH}$.

While $46.8 \%$ (161) of the TH members (integrated during the college education) identified their families as religious - based on the criterion that requires family members to undertake daily prayers $-53.2 \%$ (183) of them identified their families as non-religious. Likewise, $47.7 \%$ (164) of TH members self-identified as religious, while $52.3 \%$ (180) of them self-identified as non-religios. 
Table 2. Cross-tabulation for social structure or institutional structure versus having militants in family or relatives.

\begin{tabular}{|c|c|c|c|c|c|}
\hline \multicolumn{6}{|c|}{ IS $=1$ Other $=0 *$ militants within social structures } \\
\hline & & & $\begin{array}{l}\text { No militants } \\
\text { within } \\
\text { social structures }\end{array}$ & $\begin{array}{l}\text { Have militants } \\
\text { within social } \\
\text { structures }\end{array}$ & \\
\hline \multirow[t]{8}{*}{ IS $=1$ Other $=0$} & Other & Count & 22 & 90 & 112 \\
\hline & & $\%$ within $I S=1$ Other $=0$ & $19.6 \%$ & $80.4 \%$ & $100.0 \%$ \\
\hline & & $\begin{array}{l}\% \text { within militants within social } \\
\text { structure }\end{array}$ & $9.0 \%$ & $90.9 \%$ & $32.6 \%$ \\
\hline & & $\%$ of total & $6.4 \%$ & $26.2 \%$ & $32.6 \%$ \\
\hline & IS & Count & 223 & 9 & 232 \\
\hline & & $\%$ within IS $=1$ Other $=0$ & $96.1 \%$ & $3.9 \%$ & $100.0 \%$ \\
\hline & & $\begin{array}{l}\% \text { within Militants within social } \\
\text { structure }\end{array}$ & $91.0 \%$ & $9.1 \%$ & $67.4 \%$ \\
\hline & & $\%$ of Total & $64.8 \%$ & $2.6 \%$ & $67.4 \%$ \\
\hline \multirow[t]{4}{*}{ Total } & & Count & 245 & 99 & 344 \\
\hline & & $\%$ within IS $=1$ Other $=0$ & $71.2 \%$ & $28.8 \%$ & $100.0 \%$ \\
\hline & & $\begin{array}{l}\% \text { within Militants within social } \\
\text { structure }\end{array}$ & $100.0 \%$ & $100.0 \%$ & $100.0 \%$ \\
\hline & & $\%$ of Total & $71.2 \%$ & $28.8 \%$ & $100.0 \%$ \\
\hline
\end{tabular}

\section{Logistic regression results}

Logistic regression results are plotted in Table 3 and reveal that a one-unit increase in the $I V_{1}$ : WithOrAwayFamily (Pursuing college education while away from family) resulted in an increase in the logged odds of being integrated through institutional structures by 1.542 while holding other factors constant. As depicted in Table 3, being away from one's family came out statistically significant $(p=.000)$ for college students' integration. Due to a oneunit change in being away from one's family, increased the likelihood of being integrated through institutional structures set by the TH by nearly 4 times 'other' reasons. In other words, the $\mathrm{IV}_{1}$ (WithOrAwayFamily) has a statistically significant effect on the overall model.

These results concur with the aforementioned cross-tabulation analysis and indicate a strong role for social control/attachment in the individuals' integration into $\mathrm{TH}$. Findings support the idea that the $\mathrm{TH}$ members who were away from their families and thus had weakened social bonds (family ties), were more vulnerable to being drawn into TH through

Table 3. Logistic regression results.

\begin{tabular}{|c|c|c|c|c|c|c|c|}
\hline & & & & ables in th & juati & & \\
\hline & & $B$ & S.E. & Wald & $d f$ & Sig. & $\operatorname{Exp}(B)$ \\
\hline Step $1^{\mathrm{a}}$ & WithOrAwyFromFam & 1,542 & ,436 & 12,507 & 1 & ,000 & 4,674 \\
\hline & MilitantReligiosity &,- 416 & ,444 & 877 & 1 & 349 & 660 \\
\hline & FamilyReligiosity &,- 570 & 440 & 1,674 & 1 & 196 & ,566 \\
\hline & MilinSocStructure & $-4,527$ & ,446 & 102,935 & 1 & ,000 & ,011 \\
\hline & Constant & 2,225 & 347 & 41,234 & 1 & ,000 & 9,254 \\
\hline
\end{tabular}


strategic recruitment efforts/institutional structures designed by the violent radical group.

Furthermore, results revealed that a one-unit increase for having militants within social structures (family, relatives, and peers) $I V_{2}$ : MilinSocNetwork decreases the logged odds of being integrated through institutional structures by -4.527 while holding others constant. This coefficient is both significant and different than $0(p=.000)$. In other words, one-unit change in having militants within social network significantly increased the likelihood of college students being integrated through 'other venues' as compared to TH's institutional structures.

Results indicated that having a TH member in college students' social structure decreased the likelihood of being integrated through TH's recruitment structures. As cross-tabulation results indicate, a high percentage $(80.4 \%)$ of subjects with $\mathrm{TH}$ members in their social structure integrated into TH through kinship as opposed to TH's recruitment structures. Hence, results also indicate that among the 'others' as an integration venue, kinship (having TH militant in social structure) is a strong determinant factor for TH members' integration independent of TH's institutions. That is, the majority of subjects (16 out of 21 ) who were away from their families to attend college and had a militant in his/her close social structure at the same time, integrated into TH through the TH militants within his/her original kinship structure. Yet, out of 78 militants who attended college while living with their families (original habitat) and at the same time had a $\mathrm{TH}$ militant in their kinship circle, only six of them integrated into the TH through TH's facilitation/recruitment effort. Results support the assumption that kinship structures (family relations and relatives) had a significant impact on whether an individual joined TH. These findings are quite sensible given the feudalist structure and strong family ties in the culture of eastern Turkey where TH originated.

Interestingly, the logistic regression results indicated no significant impacts for religiosity. That is, neither militant's (MilitantReligiosity) nor their families' (FamilyReligiosity) religiosity was significantly related to how they were integrated into the $\mathrm{TH}$ : whether or not they integrated into the $\mathrm{TH}$ through the TH's institutional structures or kinship structures.

\section{Discussion of findings}

Whether integration into terrorist groups happens more through strategic recruitment or enlistment is an issue of debate. This study, to further the discussion, analyzes what family related socialization conditions (e.g. social control/bond/attachment, kinship structures) underpinned college students' integration through recruitment and enlistment. More specifically, by focusing on all college students that became $\mathrm{TH}$ militants during their college 
education, it questions how militants' family related socialization conditions affected the likelihood of integration through facilitation/recruitment or integration through individuals' wish to join.

This research finds that while radical networks' strategic recruitment structures and kinship/friendship are both significant, intentional recruitment activities designed by $\mathrm{TH}$ outperforms kinship structures at the descriptive level. However, when considering their underlying conditional dynamics separately, kinship and friendship (otherwise known as affiliative factors) are found to be very determinative factors in individuals' integration into violent radical groups, as supported by the bulk of the literature. ${ }^{139}$

On the other hand, recruitment worked more for young college students in their first years at the university who were disconnected from their familial social bonds and seeking new bonds for identity and belonging - making them more vulnerable and at-risk of being drawn into terrorist networks. ${ }^{140}$ Out of 146 college students who were attending college away from his family hometown, 127 of them were in their first year at the time of their integration into the TH. Therefore, universities, as breeding grounds for activism, are strategically exploited by $\mathrm{TH}$ and other terrorist networks. ${ }^{141} \mathrm{TH}$, through active grooming and exploitation of both physical (accommodation and certain other needs) and psychological needs (identity and belonging), drew in young college students through their institutional structures (bookstores, mosque activities, 'halaqa' meetings, and so forth) strategically designed for recruitment. So, whenever an individual has a radical militant as kin or a first circle peer in their original habitat structure, their indoctrination happened primarily through social learning (embracing radical views as group norms and definitions) and they enlisted afterward. However, those who did not have any members from radical networks in their kinship structures (families and relatives) joined through TH's intentional recruitment structures, particularly when their original control and bonds were weakened i.e. when they were disconnected from their families. ${ }^{142}$ In this regard, young college students were more vulnerable when they had weaker social bonds due to the distance from their original habitat, when they were searching for new bonds and belonging, and when they were contesting their identity.

On the other hand, religiosity in either militants or their families did not have a statistically significant effect on militants' integration into TH. This result concurs with many studies on several cases in the literature. ${ }^{143}$

In light of all this, one can say that both the recruitment and the enlistment approaches have explanatory power. However, certain sociological conditions (the lack of social control and kinship effect) might induce more vulnerability as underlying sociological factors. To better analyze and contextualize these dynamics, we briefly refer to two criminological perspectives to discuss such findings. 


\section{Social control}

Analyses in this study found that there is a statistically significant pattern for college students' integration into TH while they are away from their family and original habitat. This result indicates that weak social bonds, particularly during the individuals' first years, loosened external control over them and made them vulnerable to TH's intentionally created recruitment mechanisms. As SCT argues, strong social control is, in general, a crime deterrent and, thus, weakened social attachments/bonds put college students at more risk of recruitment by the terrorist organization. For this reason, TH intentionally set up its institutional structures around colleges and universities within metropolitan cities and provinces to take advantage of college students with diminished social bonds. Most integration occurred within the students' first years when they had not yet developed bonds to educational activities and norms around the schools.

Gibbs $^{144}$ argues that SCT can help formulate measures to discourage social deviance and thus counteract and suppress terrorism through decreasing extreme behaviors. By definition, the SCT emphasizes the role of control in terms of counteracting delinquency, stating that strong social bonds hinder delinquency. ${ }^{145}$ Britt and Gottfredson ${ }^{146}$ argue that in order to achieve its political ends terrorism requires elements of low social control. Hirschi ${ }^{147}$ assumes that everyone had the potential to become delinquent and criminal, and social control - not moral values - maintain law and order. Thus, a socially uncontrolled person is considered free to commit either terrorist or criminal acts.

According to the proponents of SCT, controlling forces restrain people from committing crimes, and weakness in these forces drives them to do so. ${ }^{148}$ Like other terrorist organizations, TH took advantage of this environment through its institutional structures, which are established wherever college students are more prone to engage them due to their weak social bonds. These institutional structures include administering bookstores, disseminating pro- $\mathrm{TH}$ journals, performing mosque-oriented activities, and so forth. For instance, TH opened bookstores in many cities to sell the Quran and other religious books; however, as discussed by Kayaoglu, ${ }^{149}$ these bookstores were set up to serve as propaganda and recruitment mechanisms through which TH militants would share their political ideologies with others. In addition, $\mathrm{TH}$ used mosque-oriented activities to engage new recruits.

In a demonstration of the importance of institutional structures on individuals' integration, one subject stated:

There were various activist groups around the college representing different ideologies. And to get involved in collective activism, I got a couple books from the 'İlim Bookstore' and met my comrades that I am with now. 
This statement suggests their receptiveness and openness for new social bonds and attachment subsequent to their physical separation from their original habitat and weakened social bonds.

Likewise, in one of the responses to how he/she first got in touch with the group, the subject stated:

I noticed a book titled 'How to Invite to Islam' in the display window of the

Selam Bookstore and I went in to buy it, but they [the bookstore personnel] were so nice to me and I was given it as a gift...

This indicates how TH's institutional structures encouraged young college students to join the organization.

Another, who was away from his/her family for college education, stated in his/her self-report that:

I started to visit the Selam Bookstore in town and I began to attend 'halaqa' via individuals I met in there.

This, again, shows how TH's bookstores worked as an effective tool in recruiting college students.

In sum, SCT emphasizes the role of control in counteracting delinquency and postulates that strong social bonds and attachments hinder delinquency, whereas weak social bonds and attachments increase one's likelihood of deviating. According to Hirschi, ${ }^{150}$ the value that individuals emotionally attribute to their relationships with significant others is the crucial element of the attachment. In this regard, the theory assumes there is a direct, inverse relationship between the likelihood of crime involvement and strength of the attachment - the stronger an individual's bond to his/her social environmental circles such as parents, family members, and close circle peers, the less likely he/she is to engage in crime.

In sum, students' first years away at college are of particular importance. This period spans from the time students left their original habitat to when they created new bonds with the society in a new environment and this condition is strategically exploited by $\mathrm{TH}$.

\section{Social learning}

SLT postulates that people attribute favorable definitions to criminal behaviors and/or learn it through modeling their observations of others. This is because SLT asserts that behaviors and ideas can be learned, and they may be supportive of criminal behavior within particular groups. ${ }^{151}$ Sutherland, Cressey, and Luckenbill $^{152}$ argue that criminal behavior is learned through a process of communication and interaction with people in intimate personal groups. The process of learning suggests that a person becomes delinquent because of an excess of definitions favorable to the violation of law over definitions unfavorable to violation 
of the law. SLT also proposes that behavior is learned not only through direct experience but also through observing one's environment. Oots and Wiegele ${ }^{153}$ argued that if aggression is viewed as learned behavior, then terrorism - a specific type of aggressive behavior - could also be learned.

Regression and cross-tabulation analyses revealed that having a $\mathrm{TH}$ member in college students' family, relatives, and close circle peer groups came out as a strong factor for students' integration into the organization. More specifically, the following statement from one of the subjects illustrates how individuals perceived and attributed favorable definitions to certain acts they observed:

... My nephew came to our house periodically. He always talked about Islamic jihad as a way of life. He always seemed quite confident and peaceful. Many people, including me, felt high respect for him, and we all were inspired by his way of life. Then I started to embrace his thoughts and precepts.

This statement indicates the element of differential association in social learning and how the subject cites favorable definitions of acts and behaviors of his/her relative. In line with Akers's ${ }^{154}$ perspective on SLT, one can argue that any individual's perception of crime may change depending on the social network where the person grew up. Thus, having criminals in one's social network increases the likelihood of an individual becoming involved in crime. Therefore, results from this study support the main theme of the social learning approach, and indicate that social structures were also responsible for integrating a high percentage of college-attending TH militants. This is not surprising at all given the culture, tight family bonds, and patriarchal family structures that are deeply embedded in the social fabric of the east and southeast part of Turkey where TH is based. ${ }^{155}$ So, it is quite normal for family members and relatives to have great power in shaping people's choices (i.e. definitions and norms).

To illustrate, one of the samples stated that:

My father is a very religious man who always supported Islam and reacted whenever Muslims and Islamic ideology were humiliated. My father has supported the Jemaah [meaning $\mathrm{TH}$ ], taught us the history and theology of Islam since I was very little. Yet, my family and I have been around the mosque and madrasa for many years. Our belief is that Islam as a concept is a perfect and just political system that would bring peace and order to our society. So I have always believed in the necessity of an Islamic organization [referring to $\mathrm{TH}]$ that has a determinative and corrective impact on society.

This suggests how the $\mathrm{TH}$ doctrine that was taught by his/her father became a norm and definition in his/her original habitat, and that he/she followed (imitated) him. This case evidences imitation - the social learning element in which an individual is more likely to engage in (criminal in this case) behaviors/acts that they observe their significant others doing. ${ }^{156}$ 


\section{Conclusion}

The purpose of this research was to analyze the conditions under which TH members integrated into the terrorist organization while they were receiving their college education. Within the dichotomy of recruitment (facilitation activities external to the individual) and enlistment (tendencies socially learned within original habitat), this study uses crime theories to identify family related sociological conditions (e.g. existence of social control/bond with the original habitat, existence of militants within kinship/friendship structures) conducive to young college students' integrating into TH. First, it finds that having a radical militant within the original habitat encourages integration into the network for a variety of reasons, some of which include identity, belonging, and group definitions and norms within individuals' personal development (imitation). Second, it finds that recruitment through TH's institutional structures among universities, book stores, mosques (Public Friday prayers) and 'halaqa' meetings are most effective when young college students have weaker social control and social bonds with their original habitat. This indicates that parental structures can play a significant role in both joining or not joining terrorist groups, but other factors, such as lack of social control, also make university students more vulnerable. Meanwhile, the religiosity of neither militants nor their families brought about a statistically significant impact on militants' integration into TH.

Two main crime theories, SCT and SLT, have explanatory power regarding college students' deviance as part of their process of integrating into TH. First, college students' physical distance from their original roots/homes weakened social bonds. Given the strong familial ties and patriarchal family structures in the eastern and southeastern parts of Turkey, where the TH has been based, having weakened social attachments/bonds, especially during the first years of study when students had not yet developed bonds and commitments to educational activities and norms at their universities, put college students at higher risk of being lured by the institutional structures TH intentionally set up around colleges and universities. In this regard, given that college students are more apt to create new bonds around the school in their first years, university-centric counter-radicalization policies may be directed at stopping terrorist networks' from exploiting these conditions. Considering the mid1990s and even today's students' residential problems and certain material needs in Turkey, intervention policies may include government-regulated, affordable housing for young students to prevent them from being drawn into such networks, filling the bond and attachment gap by increasing school-oriented campus activities, and so forth.

On the other hand, having a TH member in college students' family, relatives, and close circle peer groups was a strong factor for TH members' integration into the organization. Such a result is expectable, as it reflects the 
culture of strong social structures and family attachments in Turkey's eastern and southeastern provinces, where the TH originated. This is the hardest factor to address. How to design policy interventions for students from a relatively closed society with tight family bonds - like Turkey's southeastern provinces is a significant issue for policymakers. Approaching those individuals without stigmatizing them is important and it requires strong engagement with the communities and community leaders, who can help intervene with targeted youth (breaking off the differential association, reinforcement, and definitions) before they actually integrate into the group. For college students who have TH militants in their social structure but are studying away from their original habitat, there is a need for specialists who can approach them and intervene into the process whereby the $\mathrm{TH}$-affiliated family member connects him/her through TH's organizational network.

Overall, studying the integration process of college-attending TH members reveals that basic elements of both crime theories help explain certain conditions related to militants' family social structures. In this respect, as this study asserts, learning from family social structures has a very significant role in one's integration into violent radical group. Yet, weak social bonds have a strong explanatory power for understanding radical networks' strategic recruitment structures around universities. Thus, while policymakers should address the implications of both the recruitment and enlistment approaches, as well as from both theories of social control and social learning and design appropriate policies to help address college student's vulnerability to being drawn into $\mathrm{TH}$, for practical reasons policies should focus more on colleges and universities, where the TH's recruitment strategy and the vulnerability of the college students intersects.

\section{Notes}

1. Horgan, "Individual Disengagement," 17.

2. McGlynn and McDaid, "Radicalisation and Higher Education," 2.

3. Adam, "British Universities."

4. Harrison, "Campus Extremism."

5. Sedgwick, "The Concept of Radicalization," 480.

6. Neumann, "The Trouble," 873.

7. Spalek, "Radicalisation, De-radicalisation and Counter-radicalisation," 39.

8. King and Taylor, "The Radicalization of Homegrown Jihadists," 605.

9. Borum, "Radicalization into Violent Extremism," 2-7.

10. In this study, terms such as 'violent radical groups,' 'radical networks,' 'terrorist groups/networks' are used interchangeably as they are in the radicalization and terrorism literature.

11. Brady, Schlozman, and Verba, "Prospecting for Participants," 157.

12. Sageman, Understanding Terror Networks, 54.

13. Horgan, "Individual Disengagement," 22.

14. Borum, "Psychology of Terrorism," 12. 
15. Brown and Saeed, "Radicalization and Counter-radicalization," 158.

16. Brady, Schlozman, and Verba, "Prospecting for Participants," 159.

17. Borum, "Radicalization into Violent Extremism I," 15.

18. McGlynn and McDaid, "Radicalisation and Higher Education," 5.

19. Vold, Bernard, and Snipes, Theoretical Criminology, 185.

20. Akers et al., "Social Learning," 642.

21. Conger, "Social Control," 18.

22. Githens-Mazer and Lambert, "Why Conventional Wisdom," 894; Bouhana and Wikstrom, "Al Qai'da-Influenced Radicalisation," 2.

23. Spalek, "Radicalisation, De-radicalisation and Counter-radicalisation," 39-52; Neumann, "The Trouble," 873-93.

24. Borum, "Radicalization into Violent Extremism," 14.

25. Wuchte and Mehdi, "Countering Violent Extremism," 78.

26. Hudson and Marilyn, "The Sociology," 14.

27. Bjorgo, "Dreams and Disillusionment," 281.

28. Horgan, Individual Disengagement, 17-29.

29. Githens-Mazer and Lambert, "Why Conventional Wisdom," 890.

30. Sageman, Understanding Terror Networks; Horgan, "Deradicalization or Disengagement," 293; Stern and Amit, "Producing Terror," 259.

31. Spalek, "Radicalisation, De-radicalisation and Counter-radicalisation," 39-52.

32. Neumann, The Trouble with Radicalization, 875 .

33. Spalek, "Radicalisation, De-radicalisation and Counter-radicalisation," 39.

34. Neumann, "The Trouble," 874.

35. Davis and Cragin, Social Science, 30.

36. Pettigrew et al., "Relative Deprivation," 385-401; Runciman, Relative Deprivation.

37. Sageman, Leaderless Jihad; Silber and Arvin, Radicalization, 17.

38. Borum, "Understanding," 8; Wiktorowicz, "Joining the Cause"; Moghaddam, "The Staircase to Terrorism," 163.

39. Wright, Donald, and Moghaddam Fathali, "Responding to Membership," 997.

40. Jenkins, "Building an Army of Believers," 3.

41. Crenshaw, "The Psychology of Terrorism," 407.

42. Borum, "Understanding," 8; Wiktorowicz, "Joining the Cause"; Moghaddam, "The Staircase to Terrorism," 163.

43. Morris et al., "Deradicalization," 4.

44. McGlynn and McDaid, "Radicalisation and Higher Education," 2.

45. Wuchte and Mehdi, "Countering Violent Extremism," 81.

46. Borum, "Radicalization into Violent Extremism," 15; McGlynn and McDaid, "Radicalisation and Higher Education," 4; Wuchte and Mehdi, "Countering Violent Extremism," 79; Dean, "Criminal Profiling," 172.

47. Brady, Schlozman, and Verba, "Prospecting for Participants," 156.

48. Sageman, Understanding Terror Networks.

49. Spalek, "Radicalisation, De-radicalisation and Counter-radicalisation," 40.

50. Van San, Siekelinck, and Winter, "Ideals Adrift," 278.

51. Spalek, "Radicalisation, De-radicalisation and Counter-radicalisation," 44.

52. Bigo et al., Preventing and Countering.

53. Wali, Radicalism Unveiled, 43.

54. Hirschi, "A Control Theory," 296.

55. Sevinc, Participation in Terrorist Organizations, 12.

56. Silberman, "Religious Violence, Terrorism, and Peace," 532. 
57. Spalek, "Radicalisation, De-radicalisation and Counter-radicalisation," 41.

58. Horgan and Taylor, "A Conceptual Framework," 587; Horgan, The Psychology of Terrorism, 9.

59. Schmid, "The Links," 47.

60. Spence, "Questioning the Concept," 14.

61. Wilkenfeld et al., "The Use of Violence."

62. Ferracuti, “A Sociopsychiatric Interpretation," 132.

63. Ibid., 134.

64. Koseli, "Poverty, Inequality \& Terrorism."

65. Sageman, Understanding Terror Networks; Horgan, Individual Disengagement, 19; Stern and Amit, Producing Terror.

66. Vold, Bernard, and Snipes, Theoretical Criminology.

67. Akers et al., "Social Learning," 641.

68. Agnew, "Social Control Theory," 48; Akers et al., "Social Learning," 642; Akers and Lee, "A Longitudinal Test," 319; Liska and Reed, "Ties," 551.

69. Agnew, "A Longitudinal Test," 129; Akers and Lee, "A Longitudinal Test," 325; Matsueda and Anderson, "The Dynamics," 275; Matsueda and Heimer, "Race, Family Structure, and Delinquency," 827.

70. Borum, "Psychology of Terrorism," 15.

71. Hirschi, "A Control Theory," 289-305.

72. Akers and Jennings, The Social Learning Theory, 103-20.

73. Ibid.

74. Castello and Vowell, "Testing Control Theory," 817; Elliott, Suzanne, and Rachelle, "An Integrated Theoretical Perspective," 3-27; Matsueda and Anderson, "The Dynamics," 275.

75. Matsueda, "Testing Control Theory," 491; Agnew, “A Longitudinal Test," 12656; Elliott and Menard, "Delinquent Friends," 28-67.

76. Matsueda and Heimer, "Race, Family Structure, and Delinquency," 826-40.

77. Agnew, "A Longitudinal Test," 126-56; Akers and Lee, "A Longitudinal Test," 317-43; Elliott and Menard, "Delinquent Friends," 28-67; Matsueda and Anderson, "The Dynamics," 269-308; Matsueda, "Testing Control Theory," 489-504.

78. Elliott, Suzanne, and Rachelle, "An Integrated Theoretical Perspective," 3-27; Matsueda and Heimer, "Race, Family Structure, and Delinquency," 826-40.

79. Conger, "Social Control," 17-40.

80. Not to be confused with Lebanese Hezbollah. There is no connection between the two groups.

81. Kurt, "Kurdish Hizbullah in Turkey," 15; Nugent, "The Defeat of Turkish Hizballah."

82. This is the reason why members call the $\mathrm{TH}$ as 'cemaãt' in their own terminology.

83. Kurt, "Kurdish Hizbullah in Turkey," 19.

84. Cakir, The Reemergence of Hizballah in Turkey, 13.

85. Ibid., 5 .

86. Karmon, "Islamic Terrorist Activities," 104.

87. Unal, "Counterterrorism in Turkey," 4-9; Unal, “The Kurdistan Workers' Party (PKK) and Popular Support," 432-55.

88. Unal, "Counterterrorism in Turkey," 4-9; Unal, "Is It Ripe Yet?," 91-125.

89. In the GKK system, Turkish Army trained and armed volunteer villagers to defend themselves against the PKK. GKKs are also provided with a salary. 
90. Unal, "Strategist or Pragmatist," 422, Unal, "Counterterrorism in Turkey," 91125.

91. Unal, "Strategist or Pragmatist," 419-48.

92. Çiçek, Hangi Hizbullah [Which Hezbollah].

93. Unal, "Counterterrorism in Turkey," 4.

94. Rodoplu, Arnold, and Ersoy, "Terrorism in Turkey," 154.

95. Unal, "Counterterrorism in Turkey," 4.

96. Eligür, The Mobilization of Political Islam in Turkey.

97. Rodoplu, Arnold, and Ersoy, "Terrorism in Turkey," 87.

98. Eligür, The Mobilization of Political Islam, 87.

99. Ibid., 90.

100. Ibid., 85, 102, 135, 277.

101. Balci, "The Mobilization," 207.

102. Eligür, The Mobilization of Political Islam, 90-2.

103. Ibid., 94-5.

104. Simsek, "New Social Movements," 121.

105. Eligür, The Mobilization of Political Islam, 94.

106. Nugent, "The Defeat of Turkish Hizballah."

107. Bulut and Faraç, Kod Adr: Hizbullah.

108. Cakir, The Reemergence of Hizballah in Turkey, 11.

109. Farac, Batman'dan Beykoz'a; Çakir, "Derin Hizbullah.”

110. Sozen, "Terrorism," 138.

111. Nugent, "The Defeat of Turkish Hizballah."

112. Ibid.

113. Kurt, "Kurdish Hizbullah in Turkey," 21.

114. Ibid., 22.

115. Ibid., 28.

116. Aras and Bacik, "The Mystery of Turkish Hizballah," 152.

117. Aras and Bacik, "The Mystery of Turkish Hizballah," 149; Sozen, "Terrorism," 139.

118. Cakir, The Reemergence of Hizballah in Turkey; Farac, Batman'dan Beykoz'a.

119. Orttung and Makarychev, "National Counter-terrorism Strategies," 61.

120. Stern, Terror in the Name of God, 87.

121. Aras and Bacik, "The Mystery of Turkish Hizballah," 149-51.

122. Çiçek, Hangi Hizbullah [Which Hezbollah].

123. Sevinc, Participation in Terrorist Organizations, 34.

124. Nugent, "The Defeat of Turkish Hizballah."

125. Timeturk, HUDA-PAR'in bagimsizlari ne kadar oy aldi? http://www.timeturk. com/huda-par-in-bagimsizlari-ne-kadar-oy-aldi/haber-11971.

126. First circle peers refer to one's closest friends in his/her development into adolescence.

127. Rink and Sharma, "The Determinants of Religious Radicalization."

128. Spalek, "Radicalisation, De-radicalisation, and Counter-radicalization," 42.

129. Wali, Radicalism Unveiled.

130. Gibbs, "Conceptualization of Terrorism," 329-40.

131. McGlynn and McDaid, "Radicalisation and Higher Education," 7.

132. Spalek, "Radicalisation, De-radicalisation and Counter-radicalisation," 42; Sageman, Understanding Terror Networks.

133. Sageman, Understanding Terror Networks; Horgan, "Deradicalization or Disengagement," 292; Stern and Amit, Producing Terror. 
134. Silberman, Religious Violence, Terrorism, and Peace, 532.

135. Sevinc, Participation in Terrorist Organizations.

136. Two outsider researchers acted as inter raters for reliability tests and coding results indicated no major difference.

137. All relevant preliminary test details on the regression analysis can be shared to interested readers.

138. Chi-square test results for all cross-tabulation analyses indicated direct relationship between both variables at the $p=.000$ significance level.

139. Wuchte and Mehdi, "Countering Violent Extremism," 78; Morris et al., "Deradicalization," 3; Borum, "Radicalization into Violent Extremism," 15; King and Taylor, "The Radicalization of Homegrown Jihadists," 608.

140. Brady, Schlozman, and Verba, "Prospecting for Participants," 156; Crenshaw, "The Psychology of Terrorism," 411; Brown and Saeed, "Radicalization and Counter-radicalization," 152-96.

141. Brown and Saeed, "Radicalization and Counter-radicalization," 154.

142. Wali, Radicalism Unveiled.

143. Aly and Striegher, "Examining the Role," 850; Sageman, Understanding Terror Networks; Horgan, "Deradicalization or Disengagement," 292; Stern and Amit, Producing Terror.

144. Gibbs, Conceptualization of Terrorism, 330.

145. Booth, Farrell, and Varano, "Social Control, Serious Delinquency, and Risky Behavior," 425.

146. Britt and Gottfredson, Control Theories of Crime and Delinquency.

147. Hirschi, "A Control Theory of Delinquency," 289-305.

148. See note 66 above.

149. Kayaoğlu, Terrorism and Strain.

150. Hirschi, "A Control Theory of Delinquency," 289-305.

151. See note 66 above.

152. Sutherland, Cressey, and Luckenbill, Principles of Criminology.

153. Oots and Wiegele, "Terrorist and Victim," 3.

154. Akers, "Deviant Behavior."

155. Sevinc and Ciftci, Terrorism, Turkey, Europe, and America.

156. Akers and Jennings, The Social Learning Theory of Crime and Deviance, 105.

\section{Disclosure statement}

No potential conflict of interest was reported by the authors.

\section{Notes on contributors}

Mustafa Coşar Ünal is an Adjunct Associate Professor at Bilkent University. He received his Ph.D. in 2009 in Public Policy and Administration from the University of Maryland. He has taught graduate and undergraduate courses on terrorism, intelligence, security, and public policy at different institutions, including Bilkent University, Gazi University, Center of Excellence - Defense Against Terrorism (COE-DAT), and the Security Science Institute. His research is mostly on terrorism and other types of political violence, asymmetric conflict, conflict management and resolution, insurgency, counterinsurgency (COIN), counterterrorism (CT), COIN doctrines and strategies, intelligence, and national security. His recent publications include articles in 
journals such as Studies in Conflict and Terrorism, Terrorism \& Political Violence, Small Wars \& Insurgences, and Crime, Law, and Socia Change, as well as Counterterrorism in Turkey: Policy Choices and Policy Effects toward the Kurdistan Workers' Party (PKK) (Routledge).

Tuncay Ünal received his Ph.D. in 2010 in Public Policy and Administration from the Virginia Commonwealth University. In his professional career, he dealt with strategic and tactical level analyses on terrorism and security issues. His research is mostly on terrorism, insurgency, counterinsurgency (COIN), counterterrorism (CT), intelligence, and research methods.

\section{Bibliography}

Adam, Karla. "British Universities Sometimes Seen as Breeding Grounds for Radical Islam.” The Washington Post, January 1, 2010. Accessed October 17, 2016. http:// www.washingtonpost.com/wp-dyn/content/article/2009/12/31/AR2009123102332. html.

Agnew, Robert. “A Longitudinal Test of Social Control Theory and Delinquency." Journal of Research in Crime and Delinquency 28 (1991): 126-156.

Agnew, Robert. "Social Control Theory and Delinquency: A Longitudinal Est." Criminology; An interdisciplinary Journal 23 (1985): 47-61.

Akers, Ronald L. Deviant Behavior: A Social Learning Approach. Belmont, CA: Wadsworth, 1977.

Akers, Ronald L., Marvin D. Krohn, Lonn Lanza-Kaduce, and Marcia Radosevich. "Social Learning and Deviant Behavior: A Specific Test of a General Theory." American Sociological Review 44, no. 4 (1979): 636-655.

Akers, Ronald L., and Gang Lee. "A Longitudinal Test of Social Learning Theory: Adolescent Smoking." Journal of Drug Issues 26 (1996): 317-343.

Akers, Ronald L., and Wesley G. Jennings. "The Social Learning Theory of Crime and Deviance." In Handbook on Crime and Deviance. New York: Springer, 2004.

Aly, Anne, and Jason-Leigh Striegher. "Examining the Role of Religion in Radicalization to Violent Islamist Extremism." Studies in Conflict \& Terrorism 35 (2012): 849-862.

Aras, Bulent, and Gokhan Bacik. "The Mystery of Turkish Hizballah.” Middle East Policy 9, no. 2 (2002): 147-159.

Balci, Ali. "The Mobilization of Political Islam in Turkey." Book Review in British Journal of Middle Eastern Studies 40, no. 2 (2013): 205-207.

Bigo, Didier, Laurent Bonelli, Emmanuel-Pierre Guittet, and Francesco Ragazzi. "Preventing and Countering Youth Radicalisation in the EU Parliament, Directorate General for Internal Policies, Civil Liberties, Justice and Home Affairs Committee.” 2014. Accessed January 2017. http://www.europarl.europa. eu/RegData/etudes/etudes/join/2014/509977/IPOL-LIBE_ET(2014)509977_EN. pdf.

Bjorgo, Tore. "Dreams and Disillusionment: Engagement in and Disengagement from Militant Extremist Groups." Crime, Law and Social Change 55 (2011): 277-285.

Booth, Jeb A., Amy Farrell, and Sean P. Varano. Social Control, Serious Delinquency, and Risky Behavior: A Gendered Analysis. Crime \& Delinquency 54 (2008): 423456.

Borum, Randy. "Psychology of Terrorism." University of South Florida Tampa Department of Mental Health Law and Policy, 2007. 
Borum, Randy. "Radicalization into Violent Extremism I: A Review of Social Science Theories." Journal of Strategic Security 4 (2011): 1-36.

Borum, Randy. "Understanding the Terrorist Mindset." FBI Law Enforcement Bulletin July (2003): 7-10.

Bouhana, Noemie, and Per-Olof Wikstrom. "Al Qai'da-Influenced Radicalisation: A Rapid Evidence Assessment Guided by Situational Action Theory.” Paper presented at RDS, London, Home Office Research, 2011.

Brady, Henry E., Kay Lehman Schlozman, and Sidney Verba. "Prospecting for Participants: Rational Expectations and the Recruitment of Political Activists." American Political Science Review 93 (1999): 153-168.

Britt, Chester L., and Michael R. Gottfredson, eds. Control Theories of Crime and Delinquency. New Brunswick: Transaction, 2003.

Brown, Katherine E., and Tania Saeed, "Radicalization and Counter-radicalization at British Universities: Muslim Encounters and Alternatives." Ethnic and Racial Studies 38 (2015): 152-196.

Bulut, Faik, and Mehmet Faraç. Kod Adı: Hizbullah. Türkiye Hizbullah'ının Anatomisi. Istanbul: Ozan Yayıncilık, 1999.

Çakir, Rusen. Derin Hizbullah. İstanbul: Metis Yayıncılık. 2001.

Çakir, Rusen. The Reemergence of Hizballah in Turkey. Washington, DC: The Washington Institute for Near East Policy, 2007.

Castello, Barbara J., and Paul R. Vowell. "Testing Control Theory and Differential Association: A Reanalysis of the Richmond Youth Project Data." Criminology; An interdisciplinary Journal 37 (1999): 815-842.

Çiçek, Hikmet. Hangi Hizbullah [Which Hezbollah]. İstanbul: Kaynak Yayınları, 2000.

Conger, Rand D. "Social Control and Social Learning Models of Delinquent Behavior: A Synthesis.” Criminology; An interdisciplinary Journal 14 (1976): 17-40.

Crenshaw, Martha. "The Psychology of Terrorism: An Agenda for the 21st Century." Political Psychology 21, no. 2 (2000): 405-420.

Davis, Paul K., and Kim Cragin. Social Science for Counterterrorism: Putting the Pieces Together. Santa Monica, CA: RAND Corporation, 2009.

Dean, Geoff. "Criminal Profiling in a Terrorism Context." In Criminal Profiling: International Theory, Research, and Practice, edited by R. N. Hocsis, 169-188. Totowa, NJ: Humana Press, 2007.

Eligür, Banu. The Mobilization of Political Islam in Turkey. Cambridge: Cambridge University Press, 2010.

Elliott, Suzanne D., and Scott Menard, "Delinquent Friends and Delinquent Behavior." In Delinquency and Crime: Current Theories, edited by J. David Hawkins, 28-67. New York: Cambridge University Press, 1996.

Elliott, Suzanne D., Ageton S. Suzanne, and Canter J. Rachelle. "An Integrated Theoretical Perspective on Delinquent Behavior." Journal of Research in Crime and Delinquency 16 (1979): 3-27.

Farac, Mehmet. Batman'dan Beykoz'a Hizbullah'in Kanli Yolculugu. Istanbul: Günizi Yayıncilik, 2001.

Ferracuti, Franco. "A Sociopsychiatric Interpretation of Terrorism." The Annals of the American Academy of Political and Social Science 463 (1982): 129-140.

Gibbs, Jack P. "Conceptualization of Terrorism." American Sociological Review 54 (1989): 329-340. 
Githens-Mazer, Jonathan, and Robert Lambert. "Why Conventional Wisdom on Radicalization Fails: The Persistence of a Failed Discourse." International Affairs 86, no. 4 (2010): 889-901.

Harrison, Angela. “Campus Extremism 'A Serious Problem' Say MPs and Peers.” BBC News, April 28, 2011. Accessed May 28, 2016. http://www.bbc.co.uk/news/ education-13223026.

Hirschi, Travis. “A Control Theory of Delinquency.” In Criminology Theory: Selected Classic Readings, edited by Frank Williams and Marilyn McShane, 289-305. Cincinnati: Anderson, 1969.

Horgan, John. "Deradicalization or Disengagement? A Process in Need of Clarity and a Counterterrorism Initiative in Need of Evaluation." Revista de Psicologia Social 24 (2009): 291-298.

Horgan, John. "Individual Disengagement: A Psychological Analysis." In Leaving Terrorism Behind: Individual and Collective Disengagement, edited by Tore Bjorgo and John Horgan, 17-29. New York: Routledge, 2000.

Horgan, John. The Psychology of Terrorism. 2nd ed. New York: Routledge, 2014.

Horgan, John, and Max Taylor. "A Conceptual Framework for Addressing Psychological Process in the Development of the Terrorist." Terrorism and Political Violence 18 (2006): 585-601.

Hudson, Rex A., and Majeska Marilyn. "The Sociology and Psychology of Terrorism: Who Becomes a Terrorist and Why?” A Report Prepared Under an Interagency Agreement by the Federal Research Division, Library of Congress, Washington, DC, 1999.

Jenkins, Brain M. Building an Army of Believers: Jihadist Radicalization and Recruitment. Testimony Presented before the House Homeland Security Committee, Subcommittee on Intelligence, Information Sharing and Terrorism Risk Assessment. Santa Monica, CA: RAND Corporation, 2007.

Karmon, Ely. "Islamic Terrorist Activities in Turkey in the 1990s." Terrorism and Political Violence 10 (1998): 101-121.

Kayaoğlu, Mustafa. “Terrorism and Strain: An Exploratory Analysis of the Impact that Individual Strain and Negative Affect Have on Violent Behavior Among Trained Turkish Hezbollah Members.” PhD diss., University of North Texas, 2008.

King, Michael, and Donald M. Taylor. "The Radicalization of Homegrown Jihadists: A Review of Theoretical Models and Social Psychological Evidence." Terrorism and Political Violence 23, no. 4 (2011): 602-622.

Koseli, Mutlu. "Poverty, Inequality \& Terrorism Relationship in Turkey." PhD diss., Virginia Commonwealth University, 2008.

Kurt, Mehmet. Kurdish Hizbullah in Turkey: Islamism, Violence and the State. London: Pluto Press, 2017.

Liska, Allen E., and D. Reed Mark. "Ties to Conventional Institutions and Delinquency: Estimating Reciprocal Effects." American Sociological Review 50 (1985): 547-560.

Matsueda, Ross L. "Testing Control Theory and Differential Association: A Causal Modeling Approach.” American Sociological Review 47 (1982): 489-504.

Matsueda, Ross L., and Kathleen Anderson. "The Dynamics of Delinquent Peers and Delinquent Behavior.” Criminology; An interdisciplinary Journal 36 (1998): 269308.

Matsueda, Ross L., and Karen Heimer, "Race, Family Structure, and Delinquency: A Test of Differential Association and Social Control Theories." American Sociological Review 52 (1987): 826-840. 
McGlynn, Catherine, and Shaun McDaid. "Radicalisation and Higher Education: Students' Understanding and Experiences." Terrorism and Political Violence. Published online 2016. doi:10.1080/09546553.2016.1258637.

Moghaddam, Fathali M. “The Staircase to Terrorism: A Psychological Exploration.” American Psychologist 60 (2005): 161-169.

Morris, Madeline, Frances Eberhard, Jessica Rivera, and Michael Watsula. "Deradicalization: A Review of the Literature with Comparison to Findings in the Literatures on Deganging and Deprogramming." Institute for Homeland Security Solutions (2010): 1-13.

Neumann, Peter R. “The Trouble with Radicalization.” International Affairs 89, no. 4, (2013): 873-893.

Nugent, John T. "The Defeat of Turkish Hizballah as a Model for Counter-Terrorism Strategy." Rubin Center Research in International Affairs, 2004. Accessed May 28, 2016. http://www.rubincenter.org/2004/03/nugent-2004-03-06/.

Orttung, Robert W., and Andrey Makarychev, eds. National Counter-terrorism Strategies: Legal, Institutional, and Public Policy Dimensions in the US, UK, France, Turkey and Russia. Amsterdam: IOS Press (2006): 58-68.

Oots, Kent Layne, and Thomas C. Wiegele. "Terrorist and Victim: Psychiatric and Physiological Approaches from a Social Science Perspective." Studies in Conflict \& Terrorism 8 (1985): 1-32.

Pettigrew, F. Thomas, Oliver Christ, Ulrich Wagner, Roel W. Meertens, Rolf Van Dick, and Andreas Zick. "Relative Deprivation and Intergroup Prejudice." Journal of Social Issues 64 (2008): 385-401.

Rink, Anselm, and Kunaal Sharma. "The Determinants of Religious Radicalization: Evidence from Kenya." Journal of Conflict Resolution. Published online 2016. doi:10.1177/0022002716678986.

Rodoplu, Ulkumen, Jeffrey Arnold, and Gurkan Ersoy. "Terrorism in Turkey." Prehospital and Disaster Medicine 18, no. 2 (2003): 152-160.

Runciman, Walter Garrison. Relative Deprivation and Social Justice: A Study of Attitudes to Social Inequality in Twentieth-Century England. Berkeley: University of California Press, 1966.

Sageman, Marc. Leaderless Jihad: Terror Networks in the Twenty-first Century. Philadelphia: University of Pennsylvania Press, 2008.

Sageman, Marc. Understanding Terror Networks. Philadelphia: University of Pennsylvania Press, 2004.

Schmid, Alex P. "The Links between Transnational Organized Crime and Terrorist Crimes.” Transnational Organized Crime 2 (1996): 40-82.

Sedgwick, Mark. "The Concept of Radicalization as a Source of Confusion," Terrorism and Political Violence 22, no. 4 (2010): 479-494.

Sevinc, Bilal. Participation in Terrorist Organizations: An Analysis of Left Wing DHKP/C and Religiously Motivated Turkish Hezbollah Terrorist Organizations. PhD diss., Michigan State University, 2008.

Sevinc, Bilal, and Irfan Ciftci. Terrorism: Türkiye, Avrupa, Amerika. Ankara: Karinca Yayinlari, 2016.

Silber, Mitchell D., and Bhatt Arvin. Radicalization in the West: The Homegrown Threat. New York: NYPD Intelligence Division, 2007.

Silberman, Israela. "Religious Violence, Terrorism, and Peace." In Handbook of the Psychology of Religion and Spirituality, ed. by Raymond Paloutzian and Crystal Park, 529-549. New York: Guilford Press, 2005. 
Şimsek, Sefa. "New Social Movements in Turkey since 1980.” Turkish Studies 5, no. 2 (2004): 111-139.

Sozen, Ahmet. "Terrorism and the Politics of Anti-terrorism in Turkey." NATO Security Through Science Series Human and Societal Dynamics 14 (2006): 131-144. Spalek, Basia. "Radicalisation, De-Radicalisation and Counter-Radicalisation in Relation to Families: Key Challenges for Research, Policy, and Practice." Security Journal 29, no. 1 (2016): 39-52.

Spence, Alexander. "Questioning the Concept of 'New Terrorism." Peace Conflict \& Development 8 (2006): 1-33.

Stern, Jessica. Terror in the Name of God: Why Religious Militants Kill. New York: Ecco, 2003.

Stern, Jessica, and Modi Amit. "Producing Terror: Organizational Dynamics of Survival." In Terrorism, Security and the Power of Informal Networks, edited by David M. Jones, Anne Lane, and Paul Schulte, 257-288. Cheltenham: Edward Elgar, 2010.

Sutherland, Edwin H., Donald R. Cressey, and David F. Luckenbill. Principles of Criminology. Lanham, MD: Rowman and Littlefield, 1992.

Unal, Mustafa C. Counterterrorism in Turkey: Policy Choices and Policy Effects toward the Kurdistan Workers' Party (PKK). London: Routledge, 2012.

Unal, Mustafa C. "Is it Ripe Yet? Resolving Turkey's 30 Years Old PKK Conflict." Turkish Studies 17 (2016): 91-125.

Unal, Mustafa C. "Strategist or Pragmatist: A Challenging Look at Ocalan's Retrospective Classification and Definition of PKK's Strategic Periods Between 1973 and 2012." Terrorism and Political Violence 26 (2014): 419-448.

Unal, Mustafa C. "The Kurdistan Workers' Party (PKK) and Popular Support: Counterterrorism towards an Insurgency Nature.” Small Wars \& Insurgencies 23 (2012): 432-455.

Van San, Marion, Stjin Siekelinck, and Micha De Winter. "Ideals Adrift: An Educational Approach to Radicalization." Ethics and Education 8, no. 3, (2013): 276-289.

Vold, George B., Thomas J. Bernard, and Jeffrey B. Snipes. Theoretical Criminology. New York: Oxford University Press, 2002.

Wali, Farhaan. Radicalism Unveiled. New York: Routledge, 2013.

Wiktorowicz, Quintan. "Joining the Cause: Al-Muhajiroun and Radical Islam.” Paper presented at the roots of Islamic radicalism conference, Yale University, 2004.

Wilkenfeld, Jonathan, Victor Asal, Carter Johnson, Amy Pate, and Mary Michael. "The Use of Violence by Ethnopolitical Organizations in the Middle East." Research Brief, National Consortium for the Study of Terrorism and Responses to Terrorism, 2007. http://www.start.umd.edu/publication/use-violence-ethnopoli tical-organizations-middle-east.

Wright, Stephen C., Taylor M. Donald, and M. Moghaddam Fathali. "Responding to Membership in a Disadvantaged Group: From Acceptance to Collective Protest." Journal of Personality and Social Psychology 58 (1990): 994-1003.

Wuchte, Thomas, and Knani Mehdi. "Countering Violent Extremism and Radicalization that Lead to Terrorism: The OSCE's Unique Regional Blueprint." Journal Exit-Deutschland. Zeitschriftfür Deradikalisierung und Demokratische Kultur 2 (2013): 76-85. 